\title{
Notary Responsibility for Employee Health Insurance (Study in Mataram City)
}

\author{
Dyah Eka Suryawati*, Muhaimin ${ }^{* *}$., Muh. Risnain ${ }^{* *}$ \\ *Postgraduate program Legal Study and Notaries, Mataram University, Indonesia \\ ${ }^{* *}$ Lecture of Law Faculty Mataram University, Indonesia
}

\begin{abstract}
The title of this journal writing is the Notary's responsibility for Employee Health Insurance. The purpose of writing this journal is to (1) To analyze the arrangement of Notary's responsibility towards the employee's Health Insurance registration according to positive law, (2) To explain and analyze the application of sanctions for Notaries who have not included their employees in Health Insurance. This study uses a normative - empirical approach. The data used are primary data and secondary data. The data obtained were analyzed qualitatively and then presented in descriptive descriptions. The research results lead to a conclusion that: (1) Every company such as a Notary office is an employer, in Law No. 24 of 2011 Article 15 paragraph (1) employers are required to gradually register themselves and their workers as BPJS participants, (2) Mechanism for imposing administrative sanctions for companies that have not become participants of BPJS Kesehatan Insurance are written warnings, fines and do not receive certain public services.
\end{abstract}

Keywords: responsibilities, notaries, employees, health insurance, BPJS Kesehatan

\section{Introduction}

Notary profession is a respectable profession because their duties and positions are to serve the interests of the community, especially in the field of civil law. A notary who is also an Indonesian citizen has an obligation mentioned in Article 28J paragraph (1) of the 1945 Constitution, namely, everyone is obliged to respect the human rights of others in orderly life in the community, nation and state.

The obligation of citizens is a necessity that must not be abandoned by citizens in the life of the nation and state. The obligations of citizens can also be interpreted as an attitude or action that must be carried out by a citizen according to the privileges of other citizens. ${ }^{1}$

Before carrying out his position, the Notary is obliged to take an oath / promise according to his religion before the Minister or appointed official in which a Notary swears / promises to be obedient and loyal to the Republic of Indonesia, Pancasila and the 1945 Constitution of the Republic of Indonesia, Law about Notary Position and other laws and regulations.

Based on Article 1 paragraph (1) of Law Number 30 of 2004 concerning Notary Position as amended by Act Number 2 of 2014 concerning Notary Position: A notary is a public official authorized to make authentic deeds and has other authorities set forth in the Act This regulation or under other laws.

Law Number 30 of 2004 concerning Notary Position as amended by Act Number 2 of 2014 concerning Notary Position states:

Article 15 Paragraph (1):

\footnotetext{
${ }^{1}$ Johan Yasin, Hak Azasi Manusia dan Hak Serta Kewajiban Warga Negara dalam Hukum Positif Indonesia, Jurrnal Syiar Hukum. Vol. 11, No. 2 (2009), p.147-160
} 
"The notary is authorized to make authentic Deed regarding all acts, agreements, and stipulations required by legislation and / or desired by those concerned to be stated in authentic Deed, guarantee the date of Deed, keep Deed, provide grosse, copy and quote Deed, all of which throughout the making of the Deed are not also assigned or excluded to other officials or other people as determined by the law."

In carrying out its duties and obligations a notary does not work alone but is assisted by employees. The role of the employee is very important to complete the work of the notary in serving the services of making deeds, such as helping prepare requirements in making deeds, registering and ratifying letters or deeds made under the hands and witnessing Instrumentair, for facts as in a case of proof. The witness listed on the Notary deed is only limited to an instrumental witness (instrumentaire getuigen), meaning the witness desired by the laws and regulations. The presence of 2 (two) instrumental witnesses is absolute, but it does not mean that it must be 2 (two) people, may be more if the circumstances require. ${ }^{2}$ Without the employee in the notary's office or who can be called a worker, the work of a notary cannot run according to the plan.

The relationship between a Notary and a Worker is also called a Work Relationship, namely the relationship between workers and employers that occurs after the employment agreement. Article 1 number (15) of Law Number 13 of 2003 concerning Labor states that the relationship between employers and workers / laborers is based on a work agreement that has elements of wage work and orders. Thus, it is clear that labor relations occur because of the employment agreement between employers and workers / laborers. ${ }^{3}$

One effort that can be done by a notary to protect his employees is to provide health insurance by registering the insurance of his employees. Insurance itself can be defined as a social tool to reduce risk by combining enough exposures to make their individual losses jointly predictable. The predictable loss is then divided equally among all those who join. That definition implies that uncertainty is reduced, and losses are divided equally, this is the most important essence of insurance.

The risk that is susceptible to facing employees in assisting notary work is sickness and workplace accidents, therefore it is necessary to guarantee welfare both health protection and work. This is in accordance with the 1945 Constitution Article $28 \mathrm{H}$ paragraph (3) regulating that every person has the right to obtain social security for survival including workers.

Social security in Indonesia is divided into two namely Labor Social Security and Health Social Security and is regulated in Law Number 24 of 2011 concerning the Social Security Organizing Agency. In this Law, it regulates five Social Security programs consisting of Health Insurance managed by the Health Social Security Organizing Agency, formerly known as PT Askes (Persero) while work accident insurance, old age guarantee, pension and death insurance are managed by the Organizing Agency Labor Social Security previously named PT Jamsostek (Persero).

At this writing the focus is on Health Insurance managed by BPJS Kesehatan considering that Article $28 \mathrm{H}$ paragraph (1) of the 1945 Constitution states that:

"Everyone has the right to live in physical and spiritual prosperity, to live, and to get a good and healthy environment and the right to receive health services".

Law Number 40 of 2004 concerning the National Social Security System is mentioned in Article 1 number (11) "Workers are everyone who works by receiving salaries, wages, or other forms of remuneration" while in number (12) it is stated "Employers are individual, businessman, legal entity or other bodies that employ civil servants by paying salaries, wages or other forms of compensation ".

Law Number 24 of 2011 concerning the Social Security Organizing Body is mentioned in Article 15:

(1) Employers must gradually register themselves and their Workers as Participants in the BPJS in accordance with the Social Security program that is followed.

The employer, in registering as referred to in paragraph (1), is obliged to provide complete and correct data of himself and his workforce and family members to the BPJS.

\footnotetext{
${ }^{2}$ Sutrisno, Komentar UU Jabatan Notaris Buku II, Medan, tahun 2007, p. 37

${ }^{3}$ Lalu Husni, Pengantar Hukum Ketenagakerjaan, Jakarta, Publisher PT RajaGrafindo Persada, tahun 2014, p. 61
} 
As already known, Notary is an employer and has an obligation to register himself and his workers and family in the Health Social Security, but it is suspected that there are still many Notaries who have not implemented it even though in Act Number 24 of 2011 the Social Security Organizing Agency is said to be obligatory and will be imposed sanctions for employers or Notaries who do not carry out these obligations.

Based on the description above, it is important to conduct research because of the gap between the rules and their implementation. The formulation of the problem in this paper is as follows:

1. What is the Notary's responsibility for the registration of the employee's Health Insurance?

2. How is the implementation of sanctions for Notaries who have not included their employees in Health Insurance?

\section{Result and Discussion}

\section{Responsibilities of the Notary Registering Employees to Health Insurance}

Every company or Notary office that employs people to work in these offices must be given protection and increase the welfare of workers in the form of employment social security, because the workforce has a working relationship with the company that has the potential to increase productivity and income. For this reason, it is only natural for them to be given protection, maintenance and development towards welfare.

In Law Number 24 Year 2011 Article 15 paragraph (1) employers are required to gradually register themselves and their workers as BPJS participants. Registration of BPJS Kesehatan membership is an obligation carried out by companies that employ workers and pay wages to these workers. The company can arrange BPJS Kesehatan membership for employees can through applications provided by BPJS Kesehatan.

The company bears the costs of participant contributions to its employees with the provision of contributions set in Presidential Regulation No. 82 of 2018 concerning Health Insurance which is 5\% (five percent) of employees' fixed salary or benefits. With Details $4 \%$ (four percent) paid by the company and $1 \%$ (one percent) borne by the employee. This fee is paid by the employer directly to BPJS Kesehatan.

In Article 15 paragraph (1) of Law Number 24 of 2011 reiterates that the registration of participants of the Health Insurance for workers is obligatory to be carried out by employers, in this case of course the Company concerned, without exception. Although the company already has cooperation with other private insurance, it still must register its employees with BPJS Kesehatan. because this is a mandate from an Act that should be obeyed and implemented because with the enactment of a law and regulation to the Republic of Indonesia, everyone is considered to know it and must comply with it and implement all norms and norms. ${ }^{4}$

The Presidential Regulation of the Republic of Indonesia Number 12 of 2013 concerning Health Insurance Article 27 paragraph (2) is stated:

"Health BPJS and providers of additional health insurance programs as referred to in paragraph (1) can coordinate in providing Benefits to Health Insurance Participants who have the right to protection of additional health insurance programs".

If the company or participant wants to get additional facilities, then they can join an additional health insurance program or Coordination of Benefit (COB), namely, two or more insurance companies (BPJS Kesehatan and private insurance) bear the same person (customer) for health insurance benefits to optimize the benefits provided to customers.

The company as one of the legal subjects must obey the applicable law in this matter Law Number 24 of 2011 as a product of written and binding law. Based on the results of the elaboration above, every company in Indonesia is obliged and must register its workers as members of the BPJS Kesehatan in order to realize the provision of guarantees for the basic needs of decent living for workers in Indonesia.

\section{Implementation of sanctions for Notaries who have not included their employees in Health Insurance}

\footnotetext{
${ }^{4}$ Muchtar Rosyidi, Penuntun Peraturan Perundang-Undangan Republik Indonesia, Jakarta, PT Gramedia Pustaka Utama, 2006, p. 14
} 
Companies or Notary offices that do not include their employees in employee health means that they do not care about the welfare of employees. Health is crucial and can have an impact on employee performance, therefore the government also provides companion rules set out in the Republic of Indonesia Presidential Regulation Number 111 of 2013 concerning Amendments to Presidential Regulation Number 12 of 2013 concerning Health Insurance Article 11 paragraph 2b:

"In the event that the Worker has not been registered with the BPJS Kesehatan, the Employer must be responsible when the Worker requires health services in accordance with the Benefits provided by the BPJS Kesehatan."

The Health BPJS of Mataram throughout its establishment has invited several companies including the Notary Office to join BPJS Kesehatan participants. However, based on the data provided, not all Notary Offices in Mataram City become BPJS Kesehatan participants through Business Entity registration. Based on data from the Health BPJS of the city of Mataram, the Notary Office in the working area of Mataram City is only 7 (seven) Notary Offices that have registered themselves and their employees, namely: ${ }^{5}$

1. Notary Office of Anjarini Kencahyati S.H., M.Kn

2. Lalu's Notary Office Ade Permana S.H., M.Kn

3. Notary \& PPAT Office I Gede Sutama S.H

4. Notary Office Sri Hartati S.H

5. Notary \& PPAT Office Zulfahri S.H., M.Kn

6. Notary \& PPAT Office H. Mukhtar S.H

7. Notary Office of Ahsan Ramali S.H

The things that become obstacles in the recruitment process of BPJS Kesehatan participants are the limited number of examiners in the BPJS Kesehatan Office while the number of companies or notary offices is quite large, then in carrying out the BPJS Kesehatan examination applying priority scale which company or office with the number of workers many of which are the purpose of the inspection first.

Another obstacle is from the results of the approach to the Notary, it is known that they assume the notary office is not like a company which in its establishment requires requirements such as a company. Workers or Notary employees are also not all permanent employees and do not have contracts or work agreements. Another reason is that the Notary's office is just operating and there are no employees or employees working. ${ }^{6}$

BPJS Kesehatan The Mataram Branch Office has endeavored and will continue to strive for the success of the National Health Insurance program so that all Indonesian people receive health services. The efforts made are expected to have a good impact on increasing the number of BPJS Kesehatan participants and improving health services by all BPJS Kesehatan stakeholders.

The effort carried out by the Mataram branch of BPJS Kesehatan is to make a personal approach especially to Notaries whose working areas are in the City of Mataram. However, because not all Notaries understand the regulations regarding the BPJS Kesehatan National Health Insurance program, there are still many who have not joined as participants.

Another effort taken is the application of sanctions to the employer or company which in this discussion is a Notary in the City of Mataram. The application of these sanctions has not provided maximum results because there are still many Notary Offices that have not registered themselves, their families and employees to BPJS Kesehatan.

Sanctions are the result of an act or reaction from another party (human or social organization) for an act. In the Indonesian dictionary, sanctions are interpreted as imposition, endorsement: dependents to force others to keep promises. ${ }^{7}$ The term sanction in Dutch is called the term "sanctie", which is sanction:

\footnotetext{
${ }^{5}$ Written data from the Mataram Health BPJS branch

${ }^{6}$ Zahra khairunnisa, Relationship Officer at BPJS Kesehatan Kota Mataram, Interview on May 6, 2019

${ }^{7}$ Rizky Maulana dan Putri Amelia, Kamus Pintar Bahasa Indonesia, Surabaya, Lima Bintang, Without year, p. 366.
} 
punishment. ${ }^{8}$ So, sanctions in this discussion can be interpreted as penalties for companies that do not register workers or workers as social security participants to the BPJS Kesehatan.

In Law No. 24 of 2011 concerning BPJS there are administrative sanctions. Administrative sanctions will be imposed if the company does not carry out the obligation as employees, as stated in Article 17 paragraph (1) and (2) of Law No. 24 of 2011, namely other than state administrators who do not implement the paragraph 15 (1) and paragraph (2), and shall be subject to administrative requirements. sanctions. Subsequent regulations regarding administrative procedures and regulations regarding the procedures for imposing administrative sanctions to employees and state administrators, employees, and recipients of distribution assistance in the implementation of social security.

The procedures for imposing administrative sanctions are as follows:

1) 1) BPJS imposes written reprimand sanctions on companies that do not register their workers or workers as participants of the first social security for a maximum period of 10 (ten) days. If up to the end of the ten (10) days sanction for the first written warning, the company does not carry out its obligations, the BPJS imposes the second written warning sanction for a period of 10 (ten) days.

2) 2) Penalty penalties are imposed if after the imposition of sanctions the second written warning ends the company does not carry out its obligations. Fines are imposed at $0.1 \%$ (zero point one percent) every month from contributions that should be paid which are calculated from the second written warning ends. Then the fine is deposited with the BPJS together with the payment of the following month's contributions.

3) 3) If sanctions in the form of fines are not paid in full, the company will be subject to sanctions for not obtaining certain public services.

For example, companies in the city of Mataram who want to apply for a business license to the One Stop Integrated Service and Investment Services (DPMPTSP) of the City of Mataram must be registered as BPJS Kesehatan participants. If the company has not registered its workers with BPJS Kesehatan, the company will be reported to the Central Health BPJS and receive a warning letter.

Article 55 of the BPJS Law also regulates sanctions for employers who violate the provisions concerning payment and deposit of social security contributions, which can be punished with a maximum imprisonment of 8 (eight) years or a fine of at most Rp.1,000,000,000 (one billion rupiah).

\section{Conclusion}

Based on the description of the discussion above, conclusions can be given as follows:

1. Every company such as a Notary office is an employer, in Law No. 24 of 2011 Article 15 paragraph (1) employers are required to gradually register themselves and their workers as BPJS participants. The company bears the costs of participant contributions to its employees with the stipulation provisions stipulated in Presidential Regulation No. 19 of 2016 concerning Health Insurance which is 5\% of the employee's fixed salary or allowance. With $4 \%$ Details paid by the company and $1 \%$ borne by the employee. In Article 15 paragraph (1) Law No. 24 of 2011 reiterates that registration of health insurance participants for workers is mandatory by employers who in this case are of course the companies concerned, without exception. Even though the company already has cooperation with other private insurance, it still must register its employees with BPJS Kesehatan because this is a mandate of an Act.

2. The mechanism for imposing administrative sanctions for companies that have not become participants in the BPJS Kesehatan Insurance is the first written warning for a maximum period of 10 (ten) days. If up to the end of the ten (10) days sanction for the first written warning, the company does not carry out its obligations, the BPJS imposes the second written warning sanction for a period of 10 (ten) days. Penalty penalties are imposed if after the imposition of sanctions, the second written warning ends the company does not carry out its obligations. Fines are imposed at $0.1 \%$ (zero-point one percent) every month from contributions that should be paid which are calculated from the second written warning ends. Then the fine is deposited with the BPJS together with the payment of the following month's contributions. If sanctions in the form of fines are not paid in full, the company will be subject to sanctions for not obtaining certain public services.

${ }^{8}$ Sudarsono, Kamus Hukum, Jakarta, Rineka Cipta, 2012, p. 419. 


\section{References}

\section{Books}

[1] Sutrisno. (2007). Komentar UU Jabatan Notaris Buku II. Medan.

[2] Hasymi Ali. (1993). Pengantar Asuransi. Publisher Bumi Aksara, Jakarta.

[3] Lalu Husni. (2014). Pengantar Hukum Ketenagakerjaan. Publisher PT RajaGrafindo Persada, Jakarta.

[4] Muchtar Rosyidi. (2006). Penuntun Peraturan Perundang-Undangan Republik Indonesia. Publisher PT Gramedia Pustaka Utama, Jakarta.

[5] Rizky Maulana and Putri Amelia. Without year. Kamus Pintar Bahasa Indonesia. Publisher Lima Bintang, Surabaya.

[6] Sudarsono. (2012). Kamus Hukum. Publisher Rineka Cipta, Jakarta.

\section{Regulations}

[1] Indonesia, the 1945 Constitution of the Republic of Indonesia

[2] Law Number 2 of 2014 concerning Amendment to Law Number 30 of 2004 concerning Notary Position, State Gazette of the Republic of Indonesia Number 3 of 2014, Supplement to State Gazette Number 5491.

[3] Law Number 13 of 2003 concerning Manpower, State Gazette of the Republic of Indonesia of 2003 Number 39.

[4] L_ Law Number 24 of 2011 concerning the Social Security Organizing Agency, State Gazette of the Republic of Indonesia of 2011 Number 116, Supplement to the State Gazette of the Republic of Indonesia Number 5256.

[5] _ Law Number 40 of 2004 concerning National Social Security System, State Gazette of the Republic of Indonesia of 2004 Number 150, Supplement to the State Gazette of the Republic of Indonesia Number 4456

[6] Presidential Regulation of the Republic of Indonesia Number 82 of 2018 concerning Health Insurance, State Gazette of the Republic of Indonesia Year 2018 Number 165

[7] Republic of Indonesia Presidential Regulation Number 111 of 2013 concerning Amendments to Presidential Regulation Number 12 of 2013 concerning Health Insurance, State Gazette of the Republic of Indonesia Number 29 of 2013 